\title{
Phytochemical and Acute Toxicity Studies of Ethanol Extract from Pedada (Sonneratia caseolaris) Fruit Flour (PFF)
}

\author{
Jariyah $^{\#}$, Simon B. Widjanarko*, Yunianta ${ }^{*}$, T.Estiasih* \\ \# Department of Food Technology, Faculty of Industrial Technology, \\ University of Pembangunan Nasional "Veteran” Surabaya, Jawa Timur, Indonesia, 60294 \\ E-mail: jariyahupn65@gmail.com and jariyah_icha@yahoo.co.id \\ *Departement of Food Science and Technology, Faculty of Agriculture Technology, \\ University of Brawijaya, Malang, Jawa Timur, Indonesia, 65145 \\ E-mail: simonbw@ub.ac.id;yunianta_ub@yahoo.com;teties@yahoo.co.id
}

\begin{abstract}
Studies on the phytochemical and acute toxicity of pedada fruit flour (PFF) were carried out. In acute toxicity test, oral administration of the extract to Swiss albino mice at four levels dose, i.e. $0,10.50 ; 15.75$ and $21.00 \mathrm{~g} / \mathrm{kg}$ body weight. Phytochemical analysis of the ethanol extract of PFF showed the presence of saponins, sapogenins, terpenoids, flavonoids, tannins, polyphenols. Phytochemicals such as alkaloids were not detected. The results of acute toxicity (LD50) showed that the ethanol extract of PFF in mice was found more than $21.00 \mathrm{~g} / \mathrm{kg}$ body weight. It could be concluded that the PFF belongs to relatively less dangerous category 'non-toxic' and 'safe' for food products.
\end{abstract}

Keywords - pedada fruit flour (PFF), phytochemical, acute toxicity

\section{INTRODUCTION}

Pedada fruit is a fruit produced from one of mangrove tree species Sonneratia caseolaris. The ripened fruits have an appealing flavor and taste [1]. Some research reported that pedada fruit was used as folk medicine, analgesic, antiinflammatory properties [4], and antibacterial [16],[19]. Bioactive compound found in pedada fruit are steroids, triterpenoids, flavonoids, saponins, and tannins [4],[16],[25]. The fruits have two flavonoid types (luteolin and luteolin 7O- $\beta$ - glucoside) which function as an antioxidant [17],[25].

The flour product from pedada was commonly consumed by mangrove farmers in Wonorejo village, Surabaya, and was not known in modern community. In the other hand research about bioactive compounds from pedada fruit flour (PFF) are limited. Previous research had reported that the PFF decreased of blood glucose levels [11] and total plasma cholesterol, LDL-c, trigliceride, but not affecting the HDL-c [10], so it is potential for food ingredients, but research phytochemical on PFF has not been done. The phytochemical screening is qualitative analysis based on color reactions and/ or precipitation [27]. Furthermore the pedada fruit is not toxic [6], but be sure of its safety after processed into the flour so that acute toxicity analysis was required. In most acute toxicity test, a single dose of a test substance is given to an animal. One measure of the acute toxicity is the lethal dose $50\left(\mathrm{LD}_{50}\right)$ which is the dose of a substance that kills 50 percent of the animals tested [5],[24].

Therefore the PFF will be applied as substitution in food product, because it has pasting properties if mixed with another flour or starch [12], so this study was investigated to determine the phytochemicals and acute toxicity of ethanol PFF extract from Sonneratia caseolaris.

\section{MATERIALS AND METHODS}

\section{A. Chemicals}

Dragendorff reagent, Meyer reagent, Wagner reagent, ferric chloride $2 \%$, chloroform, n-hexane, ethyl acetate, anisaldehyde sulfuric acid, hydrochloric acid, sodium chloride, ammonium hydroxide $28 \%$, methanol, butanol.

\section{B. Extract preparation}

Fresh Pedada fruits of Sonneratia caseolaris $(50-55 \mathrm{~g} ; \pm 2$ months) were obtained from Wonorejo village, Surabaya, Indonesia. Pedada fruit flour (PFF) was processed using method by Jariyah et al. [10]. The PFF was macerated with ethanol $96 \%$ (1:3) in a stoppered container for a defined period with frequent agitation until soluble matter is dissolved. It was filtered through muslin cloth on beaker 
glass, the filtrate from ethanol extract of PFF were evaporated at $40^{\circ} \mathrm{C}, 60 \mathrm{rpm}$, stored in the refrigerator. The ethanol extract of PFF (EPFF) is ready to analyze.

\section{Phytochemical analysis}

The presence of alkaloids, saponins, sapogenins, terpenoids, flavonoids, tannins and polyphenols were determined qualitatively by using methods from YAPI Houphouet et al. [27] and Studiawan [22]. The procedure of phytochemicals analysis are as follows :

\section{1) Alkaloids test}

$5 \mathrm{ml}$ of $2 \mathrm{~N} \mathrm{HCl}$ was added to $0.3 \mathrm{~g}$ EPFF, then heated on water bath for 2-3 minutes and stirred. After cooling, $0.3 \mathrm{~g}$ $\mathrm{NaCl}$ was added and filtered. $5 \mathrm{ml}$ of $2 \mathrm{~N} \mathrm{HCl}$ was added to the filtrate and divided into three part $(\mathrm{A}, \mathrm{B}, \mathrm{C})$. Meyer reagent was added to part $\mathrm{A}$, Wagner reagent for part $\mathrm{B}$ and Dragendorff reagent for part $\mathrm{C}$. The presence of precipitation indicated the presence of alkaloids. Part $\mathrm{C}$ was analyzed by thin layer chromatography (TLC) with Kiesel gel GF 254 as stationary phase, ethyl acetate : methanol : water $(6: 4: 2)$ as mobile phase, Dragendorff reagent as appearance of spot. The appearance of orange color after spraying Dragendorff reagent indicated the presence of alkaloids.

\section{2) Saponins test}

$10 \mathrm{ml}$ distilled water was added to EPFF $0.3 \mathrm{~g}$, shaked for 30 seconds, and the foam height is measured. The foam height greater than $3 \mathrm{~cm}$ and stable for $30 \mathrm{~min}$ at a above the liquid surface indicated the presence of saponins

\section{- Sapogenins / terpenoids test}

$5 \mathrm{ml} 2 \mathrm{~N} \mathrm{HCl}$ was added to $0.5 \mathrm{~g} \mathrm{EPFF}$, boiled and covered with funnel containing a damp cotton for $2 \mathrm{~h}$ to hydrolyze saponins. After cooling, neutralized with ammonia, extracted with $3 \mathrm{ml} \mathrm{n}$-hexane for 3 times, evaporated until it reached $0.5 \mathrm{ml}$. Analysis sapogenins by TLC method is the same as alkaloids with n-hexane : ethyl acetate $(4: 1)$ as mobile phase, anisaldehyde sulfuric acid as the appearance of spot. The red purple color indicated the presence of sapogenins/terpenoids.

\section{- Flavonoids test :}

$3 \mathrm{ml} \mathrm{n}$-hexane was added to $0.3 \mathrm{~g}$ EPFF, extracted and filtered. The residue was diluted in ethanol and divided into 4 parts (A,B,C and D). The procedure of flavonoids analysis are as follows :

\section{- Bate-Smith test}

$0.5 \mathrm{ml}$ concentrated $\mathrm{HCl}$ was added to part $\mathrm{B}$, and heated. The changing color from dark red to bright red indicated the presence of flavonoids.

- Wilstater test

$0.5 \mathrm{ml}$ concentrated $\mathrm{HCl}$ was added to part $\mathrm{C}$ and also added $0.2 \mathrm{~g}$ magnesium, diluted with distilled water, stirred. Then $1 \mathrm{ml}$ butanol was added and shaked. The appearance of red orange color layer indicated the presence of flavonones.

- Thin Layer Chromatography (TLC) test for flavonoids

Spotted the filtrate D on stationary phase of Kiesel gel GF 254, with butanol-glacial acetic acid-water (4: 1: 5) as mobile phase and ammonia vapors spray is applied to make the filtrate D visible. The appearance of clear yellow spot indicated the presence of flavonoids.

\section{3) Polyphenols test :}

$10 \mathrm{ml}$ hot distilled water was added to $0.3 \mathrm{~g}$ EPFF, stirred, and let it cool in room temperature. Then 3-4 drops of 10\% $\mathrm{NaCl}$ solution was added and filtered. The filtrate was divided into 3 parts (A,B, and $\mathrm{C}$ ). A drop of aqueous solution $2 \% \mathrm{FeCl}_{3}$ was added to $4 \mathrm{ml}$ filtrate $\mathrm{A}$, the appearance of a bluish color indicated the presence of phenolic compounds. The procedure of polyphenols analysis are as follows :

- Thin Layer Chromatography (TLC) test for polyphenols

Spotted filtrate B on stationary phase of Kiesel gel GF 254, and chloroform-ethyl acetate-formic acid (0.5: 9: 0.5) as mobile phase and aqueous solution of $2 \% \mathrm{FeCl}_{3}$ as appearance of spot. The appearance of black color indicated the presence of polyphenols.

- Tannins test

A drops of aqueous $2 \% \mathrm{FeCl}_{3}$ was added to $4 \mathrm{ml}$ filtrate $\mathrm{C}$, the appearance of blackish green color indicated the presence of tannins.

\section{Acute toxicity study}

The experimental animals used for this study are white albino mice (20-32 g), 2-3 months old and were obtained from the animal unit at the Department of Pharmacognosy and Phytochemical, University of Airlangga, Surabaya, Indonesia. They were acclimatized at the animal house for seven days before the experiments. The mice were maintained ad libitum on water and growers with Comfeed Pars. The acute toxicity test of PFF extracts were carried out using a modified method of acute toxicity by Ghosh [9], and the conversion dose extract of treatment was based on Loomis [15]. The mice were divided into four group with six mice per group, and they were treated orally with $0 ; 10.50$; 15.75 and $21.00 \mathrm{~g} / \mathrm{kg}$ body weight respectively of the PFF extract. The animals were then observed every $24 \mathrm{~h}$ until 168 $\mathrm{h}$ for he acute toxicity level.

\section{RESULTS AND DISCUSSION}

\section{A. Phytochemical ethanol extract of PFF}

The results of the qualitative phytochemical composition of EPFF were presented in Table 1. It showed the presence of saponins, sapogenins, terpenoids, flavonoids, tannins, polyphenols, and alkaloids were not detected both in the precipitation reaction and thin-layer chromatography test. Although Santoso et al. [21] reported that the chloroform and methanol extract of pedada fruit showed the presence of alkaloids, Minqing et al. [16] found the presence of steroids, flavonoids, triterpenoids, and maslinic acid [26], and this acid has antihyperglycemic activity [18], this is also supported by Tiwari et al. [23] who reported that the methanol extract of the fruit pedada contains a oleanolic acid, luteolin, and $\beta$-sitosterol-3-O- $\beta$-D-glucopyranoside. 
TABLE I

RESULT OF QUALITATIVE PHYTOCHEMICAL ETHANOL EXTRACT OF PFF

\begin{tabular}{|c|c|c|c|}
\hline Constituents & Solvent & Reagent & Results \\
\hline \multirow{3}{*}{ Alkaloids } & ------------ & Mayer & ND \\
\hline & ----------- & Wagner & ND \\
\hline & ----------- & Dragendorff & ND \\
\hline Saponins & $\begin{array}{l}\text { Distilled } \\
\text { water }\end{array}$ & ----------- & ++ \\
\hline Sapogenins & $\begin{array}{l}\text { n-hexane- } \\
\text { ethyl acetic }\end{array}$ & $\begin{array}{l}\text { anisaldehyde } \\
\text { sulfuric acid }\end{array}$ & + \\
\hline Terpenoids & $\begin{array}{l}\text { n-hexane- } \\
\text { ethyl acetic }\end{array}$ & $\begin{array}{l}\text { anisaldehyde } \\
\text { sulfuric acid }\end{array}$ & + \\
\hline \multirow[t]{3}{*}{ Flavonoids } & ----------- & $\begin{array}{c}\text { Bate Smith and } \\
\text { Metcalf }\end{array}$ & +++ \\
\hline & ------------ & Wilstater & +++ \\
\hline & $\begin{array}{c}\text { Botanol- } \\
\text { acetic acid - } \\
\text { water } \\
\end{array}$ & ammonia vapor & +++ \\
\hline Tannins & ------------ & $2 \% \mathrm{FeCl}_{3}$ & +++ \\
\hline Polyphenols & $\begin{array}{l}\text { Chloroform- } \\
\text { ethyl acetic- } \\
\text { formic acid }\end{array}$ & $2 \% \mathrm{FeCl}_{3}$ & +++ \\
\hline
\end{tabular}

Note: $+++=$ relative abundance of compound,

$++=$ moderate abundance of compound;

$+=$ relative low presence of compound $\mathrm{ND}=$ not detected

The phytochemical analysis of flavonoids, tannins and polyphenols in the EPFF extract showed that this compounds are greater in quantity than the other phytochemical test. Result to the research by Sadhu et al. [19], this type of flavonoids found in pedada fruit i.e, luteolin and luteolin 7O- $\beta$-glucoside, has a hypoglycemic effect [14], an antioxidant and antidiabetic [20],[21]. The presence of tannins, flavonoids, saponins and steroids have moderate effect on the lipid profile [7], saponins as an active role in treating diabetes [3].

\section{B. Acute toxicity ethanol extract of PFF}

The results of acute toxicity ethanol extract of PFF in mice were presented in Table 2 showed that in each treatment group was not found dead mice. Treatment dosing did not influence the behaviour of mice compared to controls during the observation. A dose of $21.00 \mathrm{~g} / \mathrm{kg}$ in a single oral dose ethanol extract of PFF did not reveal any death until $168 \mathrm{~h}$ after administering test the material, so the value of a single dose oral $\mathrm{LD}_{50}$ of the ethanol extract of PFF could not be calculated, due to the absence of an animal dead. So it could be concluded that a dose of $21.00 \mathrm{~g} / \mathrm{kg}$ as the $\mathrm{LD}_{50}$ value for the ethanol extract of PFF, with category 'not toxic' and 'safe' for food product.

TABLE III

THE NUMBER OF DEAD MICE WITH ETHANOL EXTRACT OF PFF FOR $168 \mathrm{H}$

\begin{tabular}{|c|c|l|}
\hline Group (n=6) & $\begin{array}{c}\text { Ethanol extract of PFF } \\
(\mathrm{g} / \mathrm{kg} \text { body weight })\end{array}$ & $\begin{array}{l}\text { Dead of mice } \\
\text { for } 0-168 \mathrm{~h}\end{array}$ \\
\hline 1 & 0 & 0 \\
\hline 2 & 10.50 & 0 \\
\hline 3 & 15.75 & 0 \\
\hline 4 & 21.00 & 0 \\
\hline
\end{tabular}

Ukechukwu et al. [24] stated that there were not dead animals in each dose group ratings, the highest dose given to test animal, is considered as the value of $\mathrm{LD}_{50}$. In this experiment the ethanol extract of PFF contained saponins, tannins and flavonoids on acute toxicity test and did not case the death of the animals. This results reported by Kalu et al.
[13] who stated that leaf extract of Combretum dolichopentalum contain saponins, alkaloids, flavonoids also did not find any dead mice.The same result was also reported by Gadanya et al. [8].

\section{CONCLUSIONS}

This research has revealed that $\mathrm{PFF}$ is rich in phytochemical and the LD50 more than $21.00 \mathrm{~g} / \mathrm{kg}$ body weight, therefore it is 'non toxic' and 'safe' for consumption as mixture of food product.

\section{ACKNOWLEDGMENT}

Authors are grateful to staff of the Department of Pharmacognosy and Phytochemical University of Airlangga, for their advice and support during this research work.

\section{REFERENCES}

[1] W.S.S. Abeywickrama and M.C.N. Jayasooriya. Formulation and quality evaluation of cordial based on Kirila (Sonneratia caseolaris) fruit. Tropical Agricultural Research \& Extension, vol.13, No.1, pp.16-18, 2010 .

[2] M. Aslan, D.D Orhan, N. Orhan, E. Sezik and E. Yesilada. In vivo antidiabetic and antioxidant potential of Helichrysum plicatum ssp. plicatum capitulums in streptozotocin-induced-diabetic rats. Journal of Ethnopharmacology .vol.109, pp. 54-59, 2007.

[3] Atsuchi, Mikito,Yamashita, Chiaki, Iwasaki, Yoshio (2004). A Triterpenoid Saponin, Extraction There of and Use To Treat or Prevent Diabetes Mellitus. [Online]. http://www.Free Patents Online.com.

[4] W.M. Bandaranayake. Bioactive, bioactive compounds and chemical constituents of mangrove plants. Wetlands Ecology and Management. Kluwer Academic Publishers. Printed in the Netherlands. vol.10, pp.421-452, 2002.

[5] S.M. Barlow, J.B. Greig, J.W. Bridges, A. Carere, A.J.M. Carpy, C.L.Galli, J. Kleiner, I. Knudsen and H.B.W.M. Koëter, Hazard identification by methods of animal-based toxicology. Food and Chemical Toxicology. vol.40, No.2-3, pp. 145-191, 2002.

[6] L.Chen, Q. Zan, L. Mingguang, J.Shen and W.Lio. Litter dynamics and forest structure of introducted Sonneratia caseolaris mangrove forest in Shenzhen, China. Estruarine, Coastal and Self Science.vol.85, No.2, pp. 241-246, 2009.

[7] K. Dasofunjo, F.O.C. Nwodo, S.S.Ipav and T.A. Ngu. The effect of ethanolic leaf extract of Piliostigma thonningii on serum lipid profile of male wistar albino rats . J. Nat. Prod. Plant Resour. Vol.2, No.6, pp.665-669,2012.

[8] A.M. Gadanya, M. S. Sule and M. K. Atiku. Acute toxicity study of "GADAGI" tea on rats. Bayero Journal of Pure and Applied Sciences. Vol.4, No.2, pp. 147 - 149,2011.

[9] M.N. Ghosh. Fundamental of experimental pharmacology. Scientific Book Agency. Calcutta. pp.84-90, 1971.

[10] Jariyah, L. Azkiyah, S.B. Widjanarko, T. Estiasih, S.S Yuwono and Yunianta, Hypocholesterolemic Effect of Pedada (Sonneratia caseolaris) Fruit Flour in Wistar Rats. International Journal of Pharm Tech Research. vol.5, No.4, pp.1619-1627, 2013.

[11] Jariyah, S.B. Widjanarko, T. Estiasih, and Yunianta, Hyglycemic Effect of Pedada (Sonneratia caseolaris) Fruit Flour (PFF) in Alloxan-Induced Diabetic Rats. International Journal of Pharm Tech Research. vol.7, No.1, pp.31-40, 2014a.

[12] Jariyah, S.B. Widjanarko, T. Estiasih, and Yunianta, Pasting Properties Mixtures of Mangrove fruit flour (Sonneratia caseolaris) and starches . International Food Research Journal. vol.21, No.6, pp.2161-2167, 2014b.

[13] F.N.Kalu, V.N. Ogugua, C.O. Ujowundu and C.R.K. Chinekeokwu Chemical Composition and Acute Toxicity Studies on the Aqueous Extract of Combretum dolichopentalum Leaf in Swiss Albino Mice. Research Journal of Chemical Sciences . vol.1, No.8, pp.72-75, 2011.

[14] A.Lukačínová, J. Mojžiš, R. Beňačka, J. Keller, T Maguth, P. Kurila, L. Vaško, O. Rácz and F.Ništiar. Preventive Effects of Flavonoids on Alloxan-Induced Diabetes Mellitus in Rats. Acta vet. Brno. Vol. 77, pp.175-182, 2008 
[15] T.A.Loomis. Essential Of Toxicology.3rded. Lea \& Febiger,Philadelphia, 1978

[16] T. D. Minqing, H.L.Xiaoming and B. Wang. Chemical constituents of marine medical mangrove plant Sonneratia caseolaris . Chinese Journal of Oceanology and Limnology. vol. 27, No.2, pp.288-296, 2009.

[17] T. Phaechamud, K. Yodkhum, C.Limmatvapirat and P.Wetwitayaklung. Morphology, Thermal and Antioxidative Properties of Water Extracts from Sonneratia caseolaris (L) Engl. Prepared with Freeze Drying ang Spray Drying. Research Journal of Pharmaceutical, Biological and Chemical Sciences, Vol. 3. No.1, pp.725-733, 2012 .

[18] M.Rahmatullah, Md. N. K. Azam, S. Pramanik, Sania, S.Rahman and R.Jahan. Antihyperglycemic activity Evaluation of Rhizomes of Curcuma zedoaria (Christm.) Roscoe and Fruits of Sonneratia caseolaris (L.) Engl. International Journal of PharmTech Research. vol.4, No. 1, pp.125-129, 2012.

[19] S.K. Sadhu, F. Ahmed, T. Ohtsuki, and M.Ishibashi Flavonoid from Sonneratia caseolaris. Journal Nat.Med.vol.60, pp.64-265, 2006.

[20] H.K.Sandhar, B. Kumar, S. Prasher, P.Tiwari, M.Salhan and P.Sharma. A Review of Phytochemistry and Pharmacology of Flavonoids. Internationale Pharmaceutica Sciencia. Vol.1, No.1, pp. 25-41, 2011.

[21] J. Santoso, F.Febrianti and Nurjanah. Phenol content, phytochemical composition and antioxidant activity of the pedada fruits Sonneratia caseolaris. Journal of Science and Food Technologi .Vol.8, No.2, pp.1-9, 2010.
[22] H.Studiawan, 2012. Phytochemical Procedure. Faculty of Pharmacy University of Airlangga. Departement Pharmacognosy and Phytochemical. p.1-12.

[23] P.Tiwari, B.Kumar, M. Kaur, G. Kaur and H.Kaur. Phytochemical screening and extraction : A Review. International Pharmaceutica Sciencia. Vol.1, No.1, pp.98-106, 2011.

[24] U. P. C. Ukechukwu, N. F. C. Okwesili, J.E. Parker, B.Abubakar, O.C. Emmanuel and O.E. Christian. Phytochemical and acute toxicity studies of Moringa Oleifera ethanol leaf extract. International Journal of Life Sciences Biotechnology and Pharma Research. Vol.2,No.2,pp. 2250-3137, 2013.

[25] J.K.Varghese, N.Belzik, A.R. Nisha, S.Resmi and K.S. Silvipriya Pharmacognotical and phytochemical studies of a mangrove (Sonneratia caseolaris) from Kochi of Kerala State in India. Journal Pharmacy research.vol.3, No.11.pp.2625-2627, 2010.

[26] Wu Shi-Biao, Y.Wen, Li Xu-Wen, Y.Zhao, Z. Zhao and Hu Jin-Feng. Chemical constituents from the fruits of Sonneratia caseolaris and Sonneratia ovata (Sonneratiaceae). Biochem. Syst. Ecol. vol.37,pp.1$5,2009$.

[27] F. YAPI Houphouet, K. AYEBE Edwige, M. AHUA Kouassi, F YAPO Adou, F. N'guessan Marie, D. NGUESSAN Jean and J. DJAMAN Allico. Phytochemical study of crude, aqueous, methanolic and ethanolic extract of colanitida of cote d'ivoire. World Journal Pharmaceutical Research. vol.3, No.1. pp.81-88, 2013. 